\title{
E 113
}

鎌倉市役所における喫煙の現況

(職員は喫煙に対し、どう考えているか)

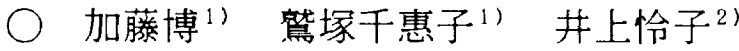 \\ 1)鎌倉市役所 職員課 2) 昭和大学・医・衛生}

【はじめに】喫煙問題に対する社会的関心が高まる中で、受動喫煙による健康への影響が指摘されている。厚生省 から平成 7 年 3 月「たばこ行動計画」が示され、これを受け労㗢省では平成 8 年 2 月「職場における喫煙対策のた めのガイドライン」を策定し、喫煙対策についての基本的な考え方が示された。本市役所においても平成 3 年以来、 安全衛生委員会において、喫煙についての検討を行ってきたが、全庁的な実施には至っていない。平成 9 年 8 月に 各部より委員を選任し、喫煙対策委員会（以下「委員会」）を発足し（図1）、市の施設における喫煙対策につい て組織的な取り組みを開始した。

喫煙規制の難しい問題として受動喫煙をはじめ、喫煙による健康影響が指摘される一方、日本では喫煙は個人の 嗜好であるという社会的認識がなお残っている点である。

【アンケート結果】実際に喫煙者、非喫煙者は喫煙についてどのように考えているのか。平成 6 年度定期健康診断 時のライフスタイル問䛦票の結果では、全職員の喫煙率は $58.5 \%$ で、そうち清掃事務所(市内 3 ケ所)の喫煙率が $71.6 \%$ と他の職域に比べ有意に高く、喫煙量(B.I.）においても全職員に比べ1.3倍有意に多い結果が得られている。 市内の清掃事務所で最も高い喫煙率を示すNクリーンセンターにおいて、「喫煙」についての調査を平成 9 年 6 月 に実施し、その結果を報告する。対象数 116人 (全男性)、回収数 111 人、回収率95.7\%である。方法は自記式ア ンケート方式で行った。(1)喫煙率は76.6\%と高く、喫煙量も1 日当り喫煙本数21本以上が $68.2 \%$ 上多い。(2)喫煙の 健康影響については、全体で $74.8 \%$ の人（喫煙者 $70.6 \%$ 、非喫煙者 $88.5 \%$ ）が「健康に相当害がある」と答えてい る。「健康に相当害がある」と考えている喫煙者のうち「禁煙・節煙を考えている」が55.0\%、「どちらも考えて いない」が40.0\%であった。「健康への影響は少ない・全くない」と考えている喫煙者で「禁煙・節煙のどちらも 考えていない」が76.0\%であった（表 1)。(3)喫煙場所については「どこでも自由に吸えるのは当然だ」が32.9\%、 「多少気が引けるが我慢出来ないので吸っている」「周りの人に断ってから吸っている」「周りに吸わない人がい る時には、吸わないようにしている」が54.2\%で、半数以上の人が周囲に気を使いながら喫煙をしている。また喫 煙量の多い（1日41本以上）人の71.4\%は「どこでも自由に吸えるのは当然だ」と答えている。(4)「たばこの煙に ついてどう感じているか」は全体では、「周りで吸っていても気にならない」が46.9\%、「何らかの苦痛や迷惑を 感じている」が42.3\%であった。䒜煙者だけでみると60.0\%は「周りで吸っていても気にならない」と答え、非喫 煙者だけでは $88.5 \%$ が「何らかの苦痛や迷惑を感じている」と訴えている。(5)喫煙の規制の方法については、全体 では「今までどおり規制する必要はない」が41.1\%、「場所（分煙）」「時間（禁煙タイム）」「全面禁煙」のい ずれかの規制が必要と答えた人が $45.9 \%$ あった。棁制の方法では場所での規制（分煙）が36.0\%上多い。また、 喫煙者だけでみると、 $51.8 \%$ の人が「今までどおり規制する必要はない」と答え、非喫煙者では $69.2 \%$ のが「分 煙・全面禁煙」を望んでいる。

以上の調査から喫煙者の多くが哪煙による健康影響を感じながら、そして周囲にも気を使いながら喫煙をしてい る状況がうかがえる。また、非哭煙者の多くは、たばこの煙による健康影響や精神的苦痛を感じている。委員会で は、この調査の結果も踏まえ、市の庁舎等における喫煙規制（喫煙場所を指定）を10年 4 月実施を目標に取り組ん でいる。春施後も、その達成状況など様々な問題が予想されるが、喫煙問題は健康問題という視点から、推進が図 れるよう努めていきたい。

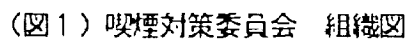

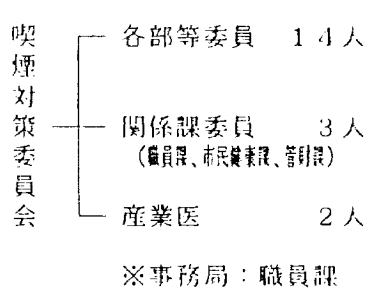

（表1）禁煙または節煙を考えていますか。

\begin{tabular}{|c|c|c|c|c|}
\hline 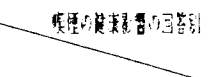 & int & 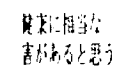 & 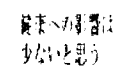 & 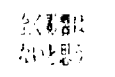 \\
\hline 涪 & $85(100 \%)$ & $60(100 \%)$ & $23(100 \%)$ & $2\left(1000_{0}^{n}\right)$ \\
\hline 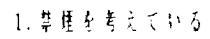 & $9(10.6)$ & $9(15.0)$ & $0(0.0)$ & $0(0.0)$ \\
\hline 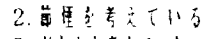 & $30(35.3)$ & $24(40.0)$ & $6(26.1)$ & $0(0.0)$ \\
\hline 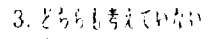 & $43(50.6)$ & $21(10.0)$ & $17(73.9)$ & $2(100.0)$ \\
\hline $1 .:$ i & $3(3.5)$ & $3(5.0)$ & $n(n . n)$ & $n(0.0)$ \\
\hline
\end{tabular}

